\title{
高分子効果を基盤とする腫瘍集積性薬剤の開発研究
}

\author{
中村秀明
}

\section{Development of Tumor-targeting Antitumor Agents Based on Polymer Effect}

\author{
Hideaki Nakamura \\ Faculty of Pharmaceutical Sciences, Sojo University; Ikeda 4-22-1, Nishi-ku, Kumamoto 860-0082, Japan.
}

(Received June 26, 2020)

\begin{abstract}
Here the author describes the tumor-selective delivery of a fluorescence photosensitizing agent and an antitumor agent, based on the polymer effect of an $N$-(2-hydroxypropyl) methacrylamide (HPMA) based copolymer, by utilizing the enhanced permeability and retention (EPR) effect seen in solid tumors. Firstly, the tumor distribution of the photosensitizer, zinc-protoporphyrin IX (ZnPP), was significantly increased by conjugation with the HPMA polymer (P-ZnPP). The P-ZnPP suppressed tumor growth by local generation of cytotoxic singlet oxygen, and the tumor tissue was visualized by fluorescence upon light irradiation. Subsequently, a two-step mechanism for tumor selectivity was observed for the cytotoxic anthracycline, pirarubicin (THP), which conjugated the HPMA-based copolymer via a hydrazone bond (P-THP). The EPR-dependent accumulation of P-THP and the tumor-selective release of THP in the tumor tissues led to highly tumor-selective toxicity. Rapid cell uptake of THP compared to other anthracyclines, and deeper P-THP penetration of the tumor cell spheroid were attributed to the superior antitumor activity of P-THP. The molecular weight of P-THP affected its antitumor activity; oligomeric P-THP derivatives with higher molecular weights, DPTHP and SP-THP, showed even higher antitumor activity. P-THP was effective for both implanted tumor and autochthonous tumor models. These results indicate that nano-sized anticancer drugs based on polymer effect are promising clinical therapeutics.
\end{abstract}

Key words_— polymer effect; enhanced permeability and retention effect; anti-tumor therapy; zinc-protoporphyrin IX; pirarubicin

\section{高分子効果に基づく高分子性抗がん斉の腫瘍集積} 低分子化合物における “ファインケミカルズ”の 概念に対応して, 高分子化学の分野においても, 高 分子化合物本来の優れた物性に, さらに種々の特異 的機能を加味させた機能性高分子の開発が進められ てきた。これは低分子化合物ではなし得なかった複 合機能の発現の可能性を与え, 高分子化学の分野に おける新たな方向性を示してきた。低分子モノマー ではみられず，ポリマーとすることで発現する特異 的な性質があり，それらは “高分子効果”之呼ばれ る. 高分子効果により溶解性や粘度など物理的性質 が変化し，新しい機能が発現することが知られてい る.さらにポリマーは生体において特徵的に挙動 し, 分子量 $40 \mathrm{kDa}$ 以上のポリマー又は高分子化合

崇城大学薬学部（干860-0082 熊本市西区池田 4-22-1） e-mail: nhideaki@ph.sojo-u.ac.jp

本総説は, 2019 年度日本薬学会九州支部奨励賞の受賞 を記念して記述したものである.
物は血中からの消失が抑制され，腫瘍組織に滞留さ せることが可能になる。このような高分子化合物の 固形腫瘍への選択的な蓄積は enhanced permeability and retention（EPR）現象に基づいており，腫瘍集 積性薬剂の開発研究において利用されている. EPR 現象による高分子化合物の腫瘍組織への集積 は，合成高分子やタンパク質のみならず，ミセルや リポソームといった化学形態の粒子に対しても観察 され，高分子性抗がん㶡の腫瘍集積メカ二ズムの基 盤となっている．高分子化合物により発現される高 分子効果に基づいた EPR 現象を利用することで, 低分子性抗がん剂の体内挙動の制御を基盤とした腫 瘍集積性薬剂の研究を行い，本総説では，（1）腫瘍 の検出と治療を目指した光増感剂一高分子コンジュ ゲート薬剤の開発と（2） pH 応答性薬物放出機能 を備えたピラルビシンー高分子コンジュゲート薬剤 の開発研究について詳述する. 
(A)

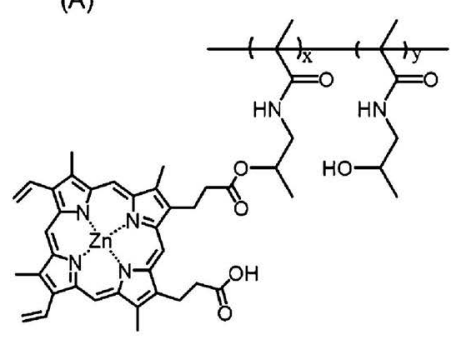

(B)

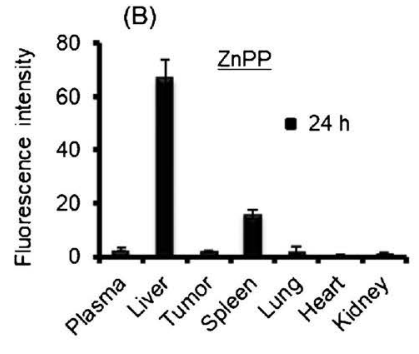

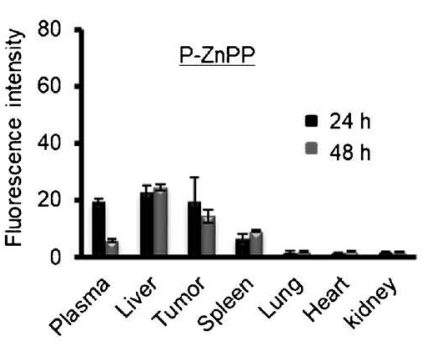

(C)

S-180 tumor model

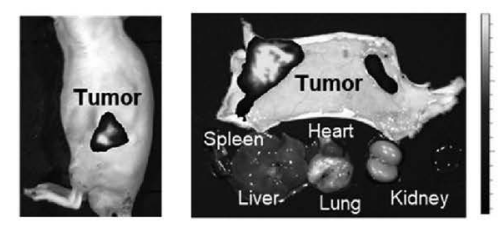

AOM/DSS induced colorectal tumor

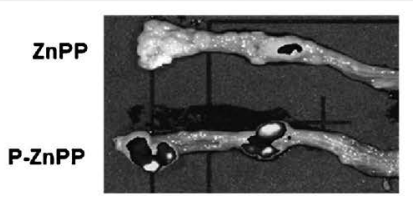

(D)

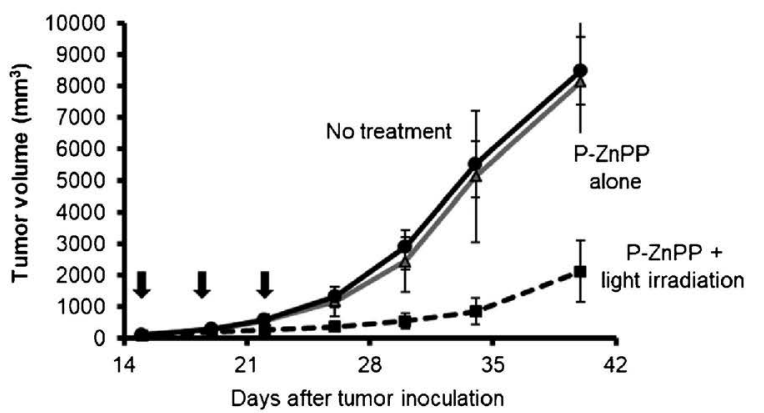

Fig. 1. Structure and Theranostic Properties of P-ZnPP

(A) Chemical structure of P-ZnPP. (B) Body distribution of ZnPP (left) and P-ZnPP (right). (C) In vivo fluorescence images of S-180 tumor (upper panel) and AOM/DSS-induced colon tumor (lower panel) treated with P-ZnPP. (D) Antitumor effect of P-ZnPP plus light irradiation in S-180 tumor-bearing mice. Arrows indicate the treatment given to mice. Reprinted from J. Control. Release, 165(3), 191-198 (2013), with permission from Elsevier.

1. 腫瘍の検出と治療を目指した光増感剤-高分 子コンジュゲート薬剤の開発 ${ }^{1,2}$

光線力学的療法は光増感剂と光照射を組み合わせ た，低侵襲的ながん治療法の 1 つである．光照射に より一重項酸素を生成（光増感作用）するポルフィ リン化合物が光増感剤としてよく用いられる，ポル フィリン化合物の多くは光照射により蛍光を発する ため, 高分子効果を利用した腫瘍組織集積型ポル フィリンの創製により，蛍光を利用した腫瘍組織の 検出が可能になり，治療と診断を同時に可能とする セラノスティック薬剤としての可能性を持つ.

亜鉛プロトポルフィリン IX (zinc-protoporphyrin IX; ZnPP) は亜鉛が配位したポルフィリン化合 物であり，細胞内抗酸化酵素であるへム酸化酵素を 阻害するという他のポルフィリンにはない特徵を有 し，抗酸化防御抑制作用と酸化傷害作用を併せ持つ 優れた光増感剂と考えられている. しかし難水溶性 のため生体への投与は困難であった。これまでに, スチレンマレイン酸（styrene maleic acid; SMA）コ ポリマーやポリエチレングリコール (polyethylene glycol; PEG）などの水溶性ポリマーを用いて可溶
化を図った SMA-ZnPP や PEG-ZnPP の検討も 行っており，優れた抗腫瘍効果を発表してきた。 ${ }^{2)}$ 本総説では後述する $N$ - (2-hydroxypropyl) methacrylamide（HPMA）ポリマーを用いた検討に関して記 述する.

HPMA ポリマーは, 1970 年代に Kopecek らに よって開発された水溶性ポリマーである。 HPMA の側鎖を修飾したコポリマーを用い，種々の薬物を 結合させたポリマー薬物複合体が多数報告されてき た。筆者は HPMA（P, Mw 12000）の側鎖に ZnPP を結合させた P-ZnPP を合成し, 光線力学的療法 へ応用した [Fig. 1 (A) ]. 1) P-ZnPP は生理的水溶 液に容易に溶解し，およそ $80 \mathrm{~nm}$ の粒子として存 在した. HPMA ポリマーへの結合後も光照射によ る一重項酸素生成能は保持しており, 光照射との併 用により細胞傷害性がみられた。担がんモデルを用 いた薬物分布では，腫瘍への ZnPP の集積はみら れなかつたが, P-ZnPP は腫瘍へ集積し, 蛍光个 メージングによる可視化が可能であった [Figs. 1 (B) and $(\mathrm{C})$ ．ささらに光照射により腫瘍の増殖が有 意に抑制された [Fig. 1（D）］。HPMA を用い 
ZnPP を水溶性高分子化することで，高分子効果に 基づく腫瘍送達型の光増感剂を創製し，治療と検出 の機能を備えたセラノスティック薬剤としての可能 性を見い出した.

2. $\mathbf{p H}$ 応答性薬物放出機能を備えたピラルビシ ンー高分子コンジュゲート薬剤の開発

EPR 現象により腫瘍組織に集積した高分子性抗 がん剂が所望の抗腫瘍効果を発揮するには，腫瘍組 織内での拡散，細胞内への取り込み及び薬物の放出 が必要である。このような課題の達成を目的とし て，精巧に分子設計された様々な送達キャリアが開 発されてきた。 それらの多くは，課題はある程度達 成できるものの, 複雑な設計・合成が施されている ため, 薬の開発という実践的な視座からは困難な要 素が含まれていた。そこで，簡便な合成手法によ り，シンプルな構造の中に，この課題達成のための 機能を付与することを企て，一連の研究に着手した.

2-1. 高分子性抗がん剤設計における内包薬物の 選択 ${ }^{3)}$ アントラサイクリン系抗がん剂のなかで もドキソルビシン（doxorubicin; DOX）は臨床で も広く使用され，さらにリポソーム製剤，高分子ミ セル製剤あるいはポリマー薬物複合体などの，高分 子性抗がん剂の active pharmaceutical ingredient （API）としても多用されている．高分子性抗がん 剂では API は不活性な積み荷として保持されてお り，送達キャリアによって腫瘍組織，ついで腫瘍細 胞内へと送達され，API を放出することで抗腫瘍 作用を発揮する。 そのため, 適切な送達キャリアの 設計が抗腫瘍効果の発現に重要であると考えられて きた。では API の選択は高分子性抗がん剂の抗腫 瘍効果にどのように影響するのか？この点に着目 して系統的な検討を行った研究報告は非常に少な い。そこで，臨床でもよく用いられるDOX，エピ ルビシン (epirubicin; EPI), 並びにピラルビシン (pirarubicin; THP) を用いて比較した.

THP 及び EPI は DOX よりも心毒性が小さいア ントラサイクリン系抗がん剂として開発された。 In vitro における性質も大きく異なり，DOX 及び EPI と比較して THP の細胞内取り込みは極めて速く, 短い接触時間においても高い細胞傷害性を示した [Figs. 2(A) and (B)]. そこで DOX 及びTHPを用 いて，腫瘍組織の環境を利用した環境応答性高分子 性抗がん剂を作製した。腫瘍組織は正常臓器とは異
なり，微酸性環境にあり，微酸性環境を送達キャリ アから API を放出させるトリガーとして利用した. HPMA を基礎としたヒドラジド基含有 HPMA コ ポリマーにヒドラゾン結合を介して DOX 又は THP を結合させた（P-DOX 又は P-THP）（Mw= 39000) [Fig. 2(C) ]. 結合薬物の違いによるサイズ 並びに, $\mathrm{pH}$ 依存的な API の放出率に差はなかつ た。 ${ }^{3)}$ 一方, P-THP 処理群では細胞内薬物量が P-DOX 処理群の 10 倍以上となった [Fig. 2(D)]. P-THP は P-DOX の 10 倍以上高い細胞傷害性を示 し，特に短いインキュベーション時間においてその 差は顕著であり，多種のがん細胞に対しても同様で あった [Fig. 2(E) ]. ${ }^{3)}$ すい臟がん皮下移植モデル を用いた薬物分布試験では両者に明確な差はみられ なかったものの, 同モデルにおける抗腫瘍効果の検 討では，P-THP はP-DOXより高い抗腫瘍効果を 示した $[$ Fig. 2(F) ]. 体重減少などの副作用に関し 両者に差はみられなかった。本研究で設計した高分 子性抗がん剂では，DOXよりも THPを API とし て使用することで, 細胞内取り込み能が増強し高い 抗腫瘍効果が得られ，高分子性抗がん剂の性質を考 慮し，API を適切に選択することで，抗腫瘍効果 を向上させることが可能であった.

\section{2-2. P-THP の腫瘍集積性と抗腫瘍効果 ${ }^{4}$}

般にポリマーへの結合は薬物の細胞内取り込みや活 性を減弱させ，P-THP においても細胞内への取り 込み及び細胞傷害性は THP と比べて 10-20 倍低下 した [Figs. 3(A) and (B) ]。 P-THP の細胞傷害性 は細胞外 $\mathrm{pH}$ に影響を受け，腫瘍組織に対応する微 酸性環境において P-THP の細胞傷害性の増強がみ られた [Fig. 3(C)]。S-180 皮下移植がんモデルに おいて，THP 投与群と比較して P-THP の正常臓 器への分布は低く, 腫瘍組織への集積がみられた [Figs. 3(D) and (E)]. さらに興味深いことに, P-THP の投与後, 活性本体である遊離 THP が腫 瘍組織に長時間に渡って滞留していた [Fig. 3 (F) ]. その結果，THP 投与群よりも腫瘍の増殖を 強く抑制し，長期にわたる生存率の改善をもたらし た [Fig. 3(G) ]. P-THP は正常臓器には集積し難 く, かつ正常臓器の $\mathrm{pH}$ では THP が放出され難い ため，P-THP の毒性は低く， ddY マウスにおける THP の $50 \%$ 致死量 $\left(\mathrm{LD}_{50}\right)$ が $14 \mathrm{mg} / \mathrm{kg}$ であるの に対し，P-THP の $\mathrm{LD}_{50}$ は $60 \mathrm{mg} / \mathrm{kg}$ とおよそ 4 倍 
(A)

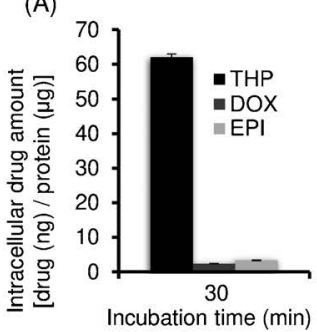

(B)

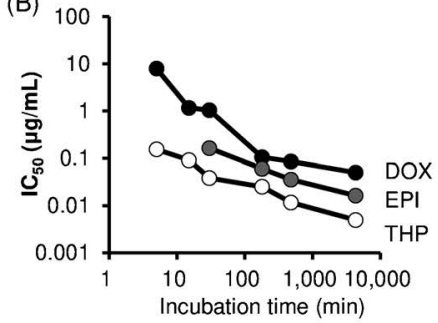

(D)

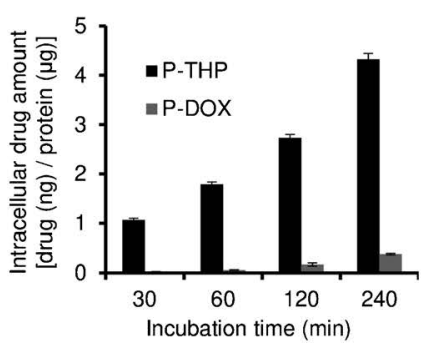

(C)

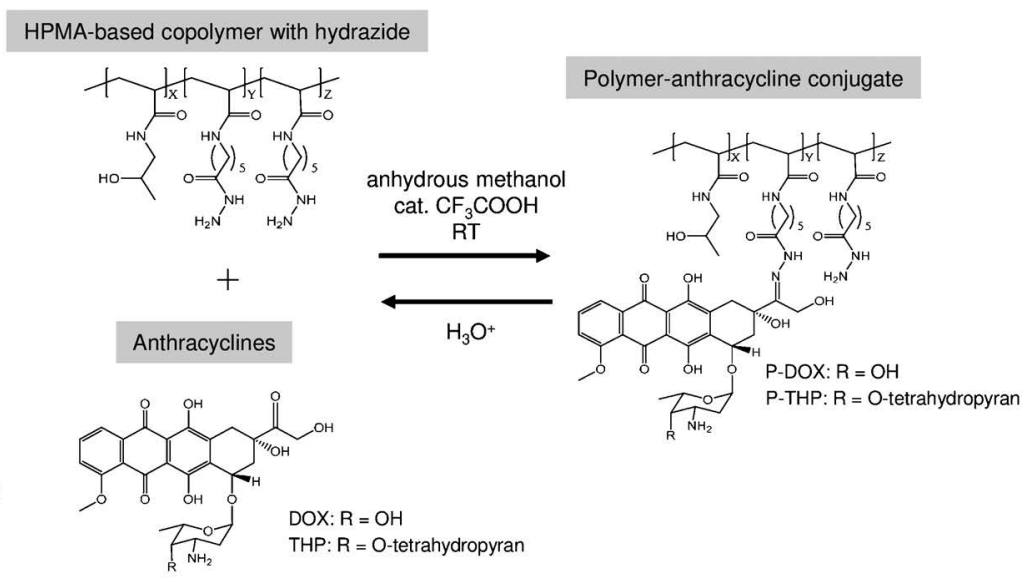

(E)

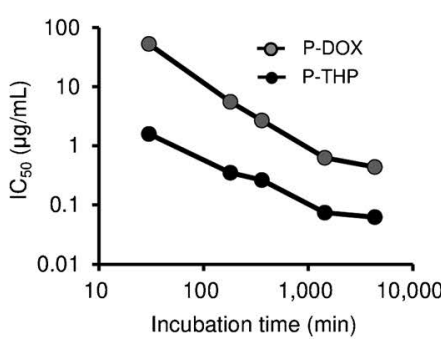

Fig. 2. Superior Antitumor Effect of P-THP Compared to P-DOX

(A) Amount of intracellular drug and (B) cytotoxicity in SUIT-2 cells treated with THP, DOX, or EPI. (C) The reaction of HPMA-based copolymer having free hydrazide with a carbonyl group on DOX or THP to form P-DOX or P-THP, respectively. (D) Amount of intracellular drug and (E) cytotoxicity in SUIT-2 cells treated with P-THP or P-DOX. (F) The antitumor effect of P-THP or P-DOX in SUIT-2 tumor-bearing mice. Arrows indicate the treatment given to mice. Reprinted with permission from Mol. Pharm., 13(12), 4106-4115 (2016). Copyright (2016) American Chemical Society.

毒性が低かつた. ${ }^{4)}$

\section{2-3. P-THP の細胞スフェロイド内拡散性 ${ }^{5}$}

高分子性抗がん剂が抗腫瘍効果を示すには，腫瘍 組織中を拡散し，腫瘍細胞に到達することが求めら れるが，高分子は拡散性が悪いため，低分子抗がん 剤と比較し腫瘍組織内での拡散には不利である。卜 ランズウェルを用いて単層培養した HCT116 細胞 層を通過できる薬物量を定量したところ，低分子で あるにもかかわらず THP は細胞層をほとんど透過 できず，DOX，EPI，及び高分子である P-THPよ りも透過量は小さかった [Fig. 4(A) ]. THP の細 胞内取り込みの速さが透過性の低さに起因し,

P-THP は細胞内への取り込みも遅く線状構造をと るため, 細胞間隙を通り透過できたと推測された.

同様の現象は腫瘍組織の in vitro モデルである細胞 スフェロイドでもみられ，THP は細胞スフェロイ ドの表層に集積したのみであったが，P-THP は細 胞スフェロイド内部まで拡散した [Figs. 4(B) and (C) ] 。 細胞への接触が容易である単層培養におい
ては，P-THP と THP の細胞傷害性は 10 倍程度の 差がみられたが，細胞スフェロイドにおいては同等 であり，P-THP のスフェロイド内拡散性が細胞傷 害性に寄与したと考えられた [Figs. 4(D) and (E)].

腫瘍組織内の $\mathrm{pH}$ は一様ではなく，血管から離れ るに従い pH が低下する。P-THP は腫瘍組織への デリバリー並びに腫瘍組織内拡散性を持ち, 組織内 を拡散するに従い $\mathrm{pH}$ の低下とともに徐々に THP を放出することで高い抗腫瘍効果を発揮すると推測 された。一方, 正常臓器には分布し難く, さらに細 胞傷害性を示す THP の放出が抑制され，毒性を示 し難い。このように P-THP は非常に簡潔な構造の 中に，腫瘍組織集積性，組織内拡散性並びに優れた 細胞内取り込みを併せ持った高分子抗がん剤である と考えられた。

2-4. 分子サイズの異なる P-THP 誘導体の抗腫 瘍効果 ${ }^{6-8)}$ HPMA ポリマーは生分解性が悪く,

$\mathrm{Mw}$ が 70000 以上のフラクションは生体内に蓄積す るため，予期しない副作用が懸念される，P-THP 


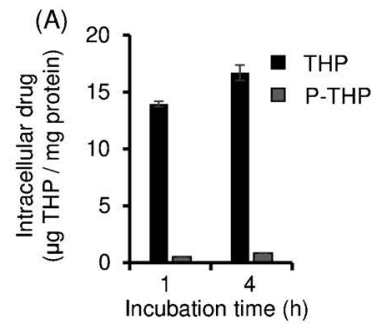

(B)

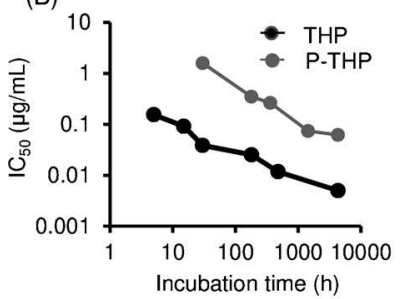

(E)

(D)
(C)

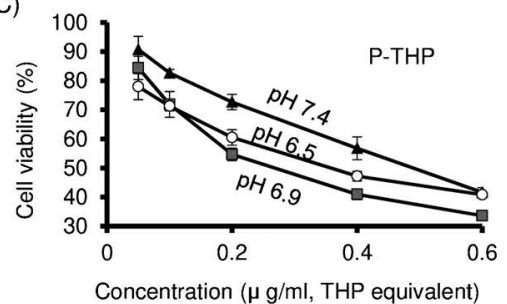

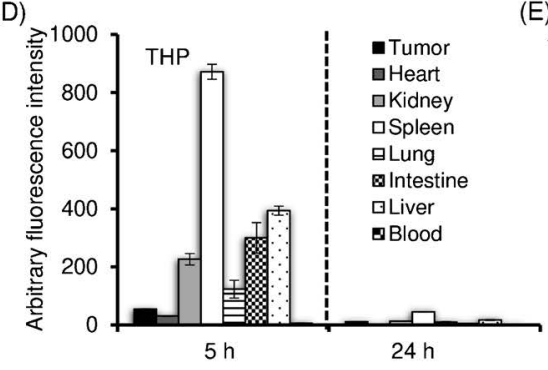

(F)

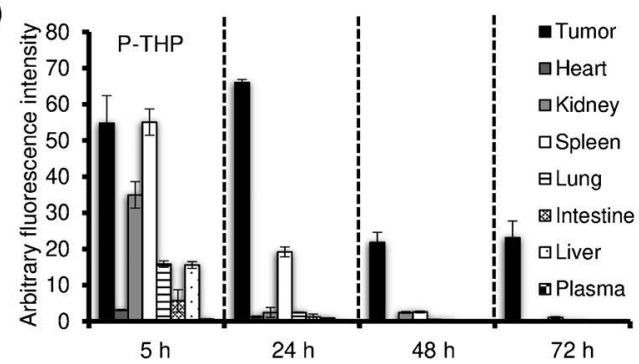

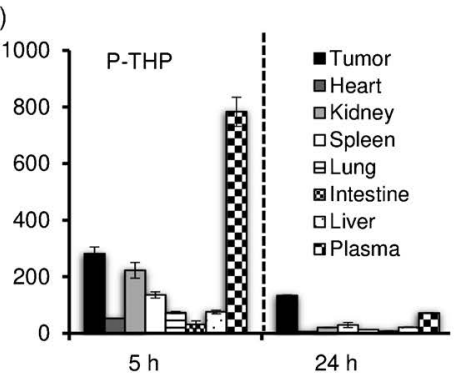

(G)

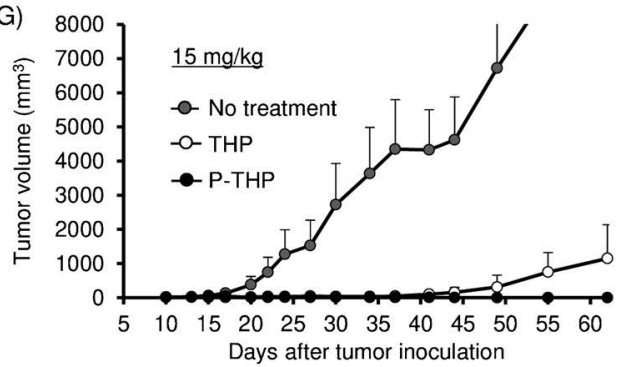

Fig. 3. Superior Antitumor Effect of P-THP Compared to THP

(A) Amount of intracellular drug and (B) cytotoxicity in HeLa cells treated with THP or P-THP. (C) Cytotoxicity of P-THP at different pH values. (D, E) Body distribution of the total-THP in S-180 tumor-bearing mice administered (D) THP or (E) P-THP. (F) Released free THP distribution in mice administered PTHP. (G) Antitumor activity of P-THP and THP in S-180 tumor-bearing mice treated with $5 \mathrm{mg} / \mathrm{kg}$ THP equivalent dose of THP and P-THP. Reprinted from $J$. Control. Release, 174, 81-87 (2014), with permission from Elsevier.
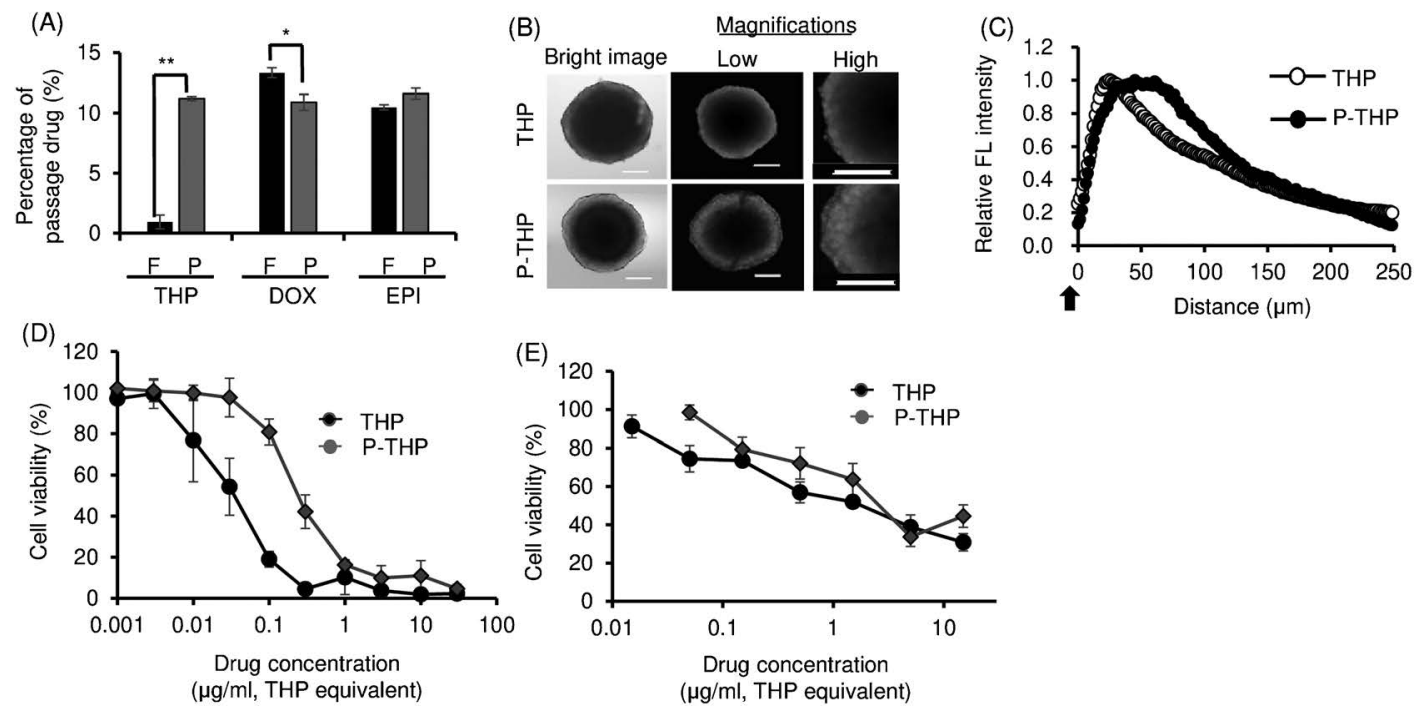

Fig. 4. Diffusion of P-THP in Cell-spheroid

(A) The amount of drug passage through the HCT 116 monolayer cells. THP, DOX, and EPI, indicated as F, and polymer-drug conjugates as free drug equivalent indicated as P. (B) Images of a spheroid treated with THP or P-THP. Scale bar indicates $200 \mu \mathrm{m}$ length. (C) The relative fluorescence intensity profile of spheroids treated with THP or P-THP. (D, E) Cytotoxicity of THP and P-THP in HCT 116 cells cultured in (D) monolayer or (E) spheroid. ${ }^{*} p<0.05$, ${ }^{* *} p<0.01$. Reprinted with permission from Mol. Pharm., 16(8), 3452-3459 (2019). Copyright (2019) American Chemical Society. 


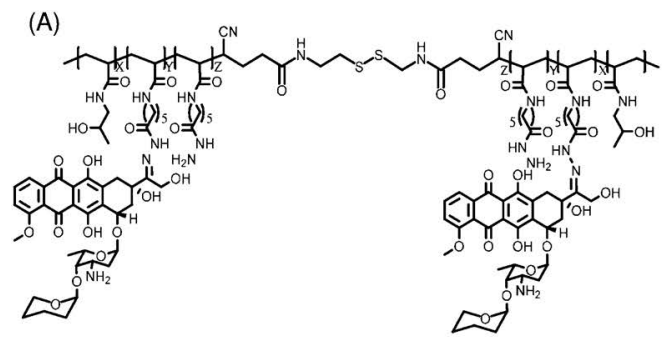

(C)

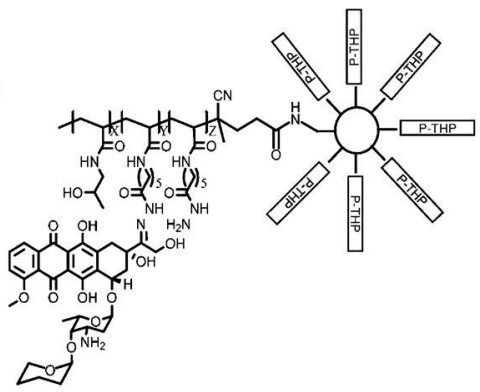

(B)

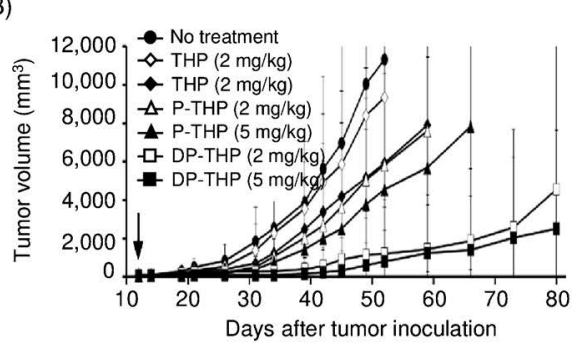

(D)

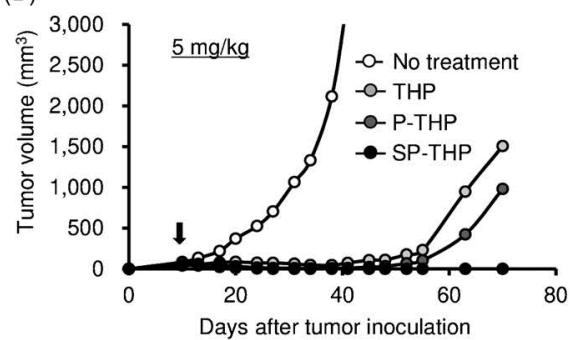

Fig. 5. Antitumor Effect of DP-THP and SP-THP

(A, C) Chemical structures of (A) DP-THP and (C) SP-THP. (B, D) Antitumor activity of (B) DP-THP and (D) SP-THP in S-180 tumor-bearing mice. Arrows indicate the treatment given to mice. Reprinted from Eur. J. Pharm. Biopharm., 90, 90-96 (2015) and Eur. J. Pharm. Biopharm., 106, 10-19 (2017), with permission from Elsevier.

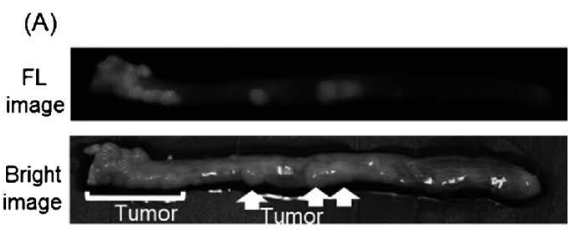

(B)

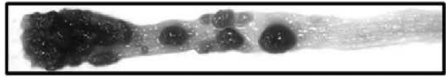

(C)

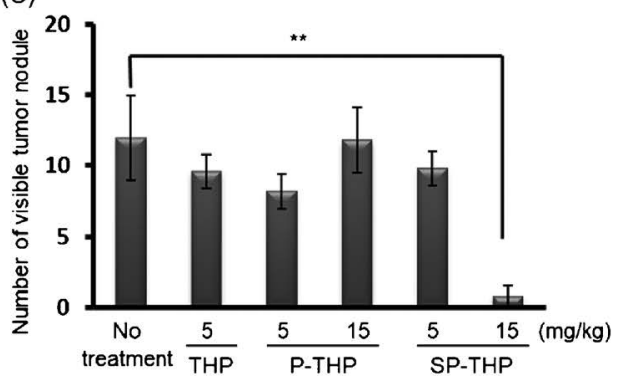

Fig. 6. Antitumor Effect of SP-THP in an AOM/DSS-induced Colon Tumor Model

Fluorescence (A, upper) or brightfield (A, lower, and B) image of the colon of the AOM/DSS colon tumor model after treatment with cy5-BSA or EB. (C) Antitumor activity of THP, P-THP, and SP-THP in the AOM/DSS-induced colon tumor-bearing mice. ${ }^{* *} p<0.01$. Reprinted from Eur. J. Pharm. Biopharm., 90, 90-96 (2015), with permission from Elsevier.

では安全性を考慮し，ポリマー中に含まれる $\mathrm{Mw}$ $>60000$ が $10 \%$ 以下となるように分子量の調整を 行い作製した。そのため低分子フラクションも含ま れ，血中投与 24 時間後にはおよそ $70 \%$ が排泄され る. そこで, P-THP の基本構造を維持しつつ, ダ イマー, デンドリマー構造といつた大きいサイズの P-THP，それぞれ DP-THP 及び SP-THP を作製し 抗がん効果への影響を検討した。

DP-THP は P-THP をジスルフィド結合でタンデ ムに連結した構造を持つ [Fig. 5(A)]。還元型グル タチオンにより P-THPへと分解されるため, 蓄積 毒性を回避し分子量を大きくした設計である，分子 量は $\mathrm{Mw}=93000$ であり，遊離 THP の放出速度や 細胞傷害性に違いはなかった。一方，P-THPの 3-
5 倍ほど腫瘍への集積量が多く，低投与量で長期間 にわたつて腫瘍の増殖を抑制した [Fig. 5(B)]。単 回投与毒性で $\mathrm{LD}_{50}$ を比較したところ, $\mathrm{ddY}$ マウス において P-THP と比較し DP-THP は 1.3 倍程度の 毒性の増大がみられた。

SP-THP は PAMAM デンドリマーの末端にPTHP を結合した構造で，分子量はおよそ $\mathrm{Mw}=$ 400000 である [Fig. 5 (C) ].S-180 皮下移植がんモ デルにおいて，腫瘍集積量が P-THP 投与群より 28 倍高かった。 ${ }^{6}$ 腫瘍集積性の向上に伴い, 抗腫瘍 効果の向上もみられた $[\mathrm{Fig} .5(\mathrm{D})]$. 一方, ddY マ ウスにおいて SP-THP の $\mathrm{LD}_{50}$ は $23 \mathrm{mg} / \mathrm{kg}$ と PTHP の 2.5 倍程度の毒性の増大がみられた。分子 量の増大とともに血中滞留性が向上するが，ヒドラ 
ゾン結合は緩徐ではあるが血中においても加水分解 をうけるため, THP が血中で放出され毒性の増大 に寄与したと考えられた。

2-5. 自然発症がんにおけるP-THP の抗腫瘍効 果6) 抗がん効果の検証には同種異所性移植モデ ルや異種異所性移植モデルがよく用いられる。これ らのモデルは技術的な簡便さ，短時間で作製できる など多くのメリットを有するが，かならずしも実際 のがんを反映していないと指摘される。自然発症が んモデルは，がんの発生過程及びがんの組織構造が 再現されたモデルであり, 化学発がん剂や遺伝子改 変マウスを用いて作製される. 田中らの方法に従い, ICR マウスに $10 \mathrm{mg} / \mathrm{kg}$ のアゾキシメタン（azoxymethane; AOM） の投与及び $2 \%$ デキストラン硫酸 ナトリウム（dextran sulfate sodium; DSS）を自由 飲水させ，12 週間飼育することで炎症関連大腸が んモデルを作製した. ${ }^{9)} \mathrm{Cy} 5$ 標識ウシ血清アルブミ ン（Cy5-BSA）又はエバンスブルー（Evans blue; EB）の投与により隆起を伴う腫瘍部に Cy5-BSA 又 はEB の集積がみられ，本モデルにおいても EPR 効果はみられた [Figs. 6(A) and (B)]。AOM/DSS 投与 12 週後に P-THP を投与し， 4 週後に抗腫瘍効 果を検討した。腫瘍結節数並びに腫瘍面積を指標に して抗腫瘍効果を検討したところ，P-THP の投与 では抗腫瘍効果はみられなかったが，SP-THP の投 与により有意に抑制した $[\mathrm{Fig} .6(\mathrm{C})]$ 。単回投与の みであり，かならずしも P-THP の非有効性を示す ものではないが，SP-THP の高い抗腫瘍効果が確認 され，自然発症がんモデルにおいても有効であるこ とを示した

おわりに

これまでに種々の高分子性抗がん剤が研究開発さ れてきた。一方，臨床においては非臨床試験から期 待されるほどの優れた治療効果が観察されない事例 も多く, 動物モデルとヒトがんとの違いがしばしば 指摘されている．現在，筆者は，これらの違いを考 慮した高分子性抗がん剂の設計並びに EPR 効果増 強剤などの研究を進めている，副作用に悩まされる ことなく効果の高い抗がん剂を臨床に届けられるよ
うに研究を進めていきたい.

謝辞 これらの一連の研究を行うにあたり，多 大なるご助言及びご協力を賜わりました，バイオダ イナミクス研究所 前田 浩先生, チェコ科学アカ デミー高分子化学研究所 Tomas Etrych 博士, 並び に崇城大学薬学部 原武 衛先生に感謝の意を表し ます。

利益相反＼cjkstart開示すべき利益相反はない.

\section{REFERENCES}

1) Nakamura H., Liao L., Hitaka Y., Tsukigawa K., Subr V., Fang J., Ulbrich K., Maeda H., J. Control. Release, 165, 191-198 (2013) .

2) Nakamura H., Fang J., Gahininath B., Tsukigawa K., Maeda H., J. Control. Release, 155, 367-375 (2011).

3) Nakamura H., Koziolová E., Chytil P., Tsukigawa K., Fang J., Haratake M., Ulbrich K., Etrych T., Maeda H., Mol. Pharm., 13, 4106-4115 (2016).

4) Nakamura H., Etrych T., Chytil P., Ohkubo M., Fang J., Ulbrich K., Maeda H., J. Control. Release, 174, 81-87 (2014).

5) Nakamura H., Koziolová E., Chytil P., Etrych T., Haratake M., Maeda H., Mol. Pharm., 16, 3452-3459 (2019).

6) Nakamura H., Koziolová E., Etrych T., Chytil P., Fang J., Ulbrich K., Maeda H., Eur. J. Pharm. Biopharm., 90, 90-96 (2015).

7) Etrych T., Tsukigawa K., Nakamura H., Chytil P., Fang J., Ulbrich K., Otagiri M., Maeda H., Eur. J. Pharm. Sci., 106, 10-19 (2017).

8) Randárová E., Nakamura H., Islam R., Studenovský M., Mamoru H., Fang J., Chytil P., Etrych T., Acta Biomater., 106, 256-266 (2020).

9) Tanaka T., Kohno H., Suzuki R., Yamada Y., Sugie S., Mori H., Cancer Sci., 94, 965-973 (2003). 